Geo-Marine Letters

\title{
Seafloor character and sedimentary processes in eastern Long Island Sound and western Block Island Sound
}

\author{
L.J. Poppe ${ }^{1}-$ M.L. DiGiacomo-Cohen ${ }^{2}-$ S.M. Smith ${ }^{3}$ - H.F. Stewart ${ }^{3}$ - N.A. Forfinski ${ }^{3}$ \\ ${ }^{1}$ Coastal and Marine Geology Program, U.S. Geological Survey, Woods Hole, MA 02543, USA \\ lpoppe@usgs.gov \\ ${ }^{2}$ Long Island Sound Resource Center, Connecticut Department of Environmental Protection, \\ Avery Point, Groton, CT 06340, USA \\ ${ }^{3}$ Atlantic Hydrographic Branch, National Oceanic Atmospheric Administration, Norfolk, VA \\ 23510, USA
}

\begin{abstract}
Multibeam bathymetric data and seismic-reflection profiles collected in eastern Long Island and western Block Island Sounds reveal previously unrecognized glacial features and modern bedforms. Glacial features include an ice-sculptured bedrock surface, a newly identified recessional moraine, exposed glaciolacustrine sediments, and remnants of stagnant-ice-contact deposits. Modern bedforms include fields of transverse sand waves, barchanoid waves, giant scour depressions, and pockmarks. Bedform asymmetry and scour around obstructions indicate that net sediment transport is westward across the northern part of the study area near Fishers Island and eastward across the southern part near Great Gull Island.
\end{abstract}

\section{Introduction}

Digital terrain models (DTMs) produced from multibeam bathymetric data provide valuable base maps for marine geological interpretations (Todd et al. 1999; Mosher and Thomson 2002; ten Brink et al. 2004; Poppe et al. 2006). These maps help define the geological variability of the seafloor (one of the primary controls of benthic habitat diversity); improve our understanding of the processes that control the distribution and transport of bottom sediments and the distribution of benthic habitats and associated infaunal community structures; and provide a detailed framework for future research, monitoring, and management activities.

The bathymetric survey interpreted herein (National Oceanic and Atmospheric Administration (NOAA) survey H11250) covers roughly $94 \mathrm{~km}^{2}$ of seafloor in an area where a depression along the Orient Point-Fishers Island segment of the Harbor Hill-Roanoke PointCharlestown Moraine forms the Race, the eastern opening to Long Island Sound. The Race also divides easternmost Long Island Sound from northwestern Block Island Sound (Fig. 1). This bathymetry has been examined in relation to seismic reflection data collected concurrently, as well as archived seismic profiles collected as part of a long-standing geologic mapping partnership between the State of Connecticut and the U.S. Geological Survey (USGS). The objective of this work was to use these acoustic data sets to interpret geomorphological attributes of the seafloor, and to use these interpretations to better understand the Quaternary geologic history and modern sedimentary processes.

\section{Geologic setting}


Bedrock that underlies southeastern Connecticut and, presumably, the survey area consists of Precambrian (?) and Paleozoic gneisses and granites of the Avalonian Terrane (Rodgers 1985). Together, these rocks form an anticlinorium that is locally intruded by the Westerly Granite (Permian?), a fine-grained component of the Narragansett Pier Plutonic Suite (Rodgers 1985; Hermes et al. 1994). Drill holes have encountered crystalline bedrock at about $-86 \mathrm{~m}$ under Fishers Island (Fuller 1905), and at $-152 \mathrm{~m}$ under Orient Point on Long Island (Suter et al. 1949). The bedrock under eastern Long Island Sound and Block Island Sound was acoustically mapped, revealing a southward-dipping surface cut by south-southeast-trending bedrock valleys (Grim et al. 1970; McMaster and Ashraf 1973; Needell and Lewis 1984; Lewis and Needell 1987).

Coastal-plain sediments of Cretaceous age, consisting of unconsolidated to semiconsolidated gravels, sands, silts, and clays, have been reported on Block Island and along the north shore of Long Island (Fuller 1914; Sirkin 1976; Suter et al. 1949). McMaster et al. (1968) identified a seaward-dipping, erosional remnant of the coastal-plain strata overlying bedrock unconformably in the southern portion of Block Island Sound. The cuesta formed by this remnant can be traced westward to Plum Island (Needell and Lewis 1984). Although the cuesta scarp has been mapped well south of Fishers Island, Needell and Lewis (1984) inferred that some coastalplain sediment extends under western Fishers Island and Fuller (1905) interpreted blue clay resting on granite in a well on Fishers Island to be of Cretaceous age.

In southeastern Connecticut and on the north shore of Long Island, bedrock and/or coastalplain strata are unconformably overlain by two glacial drift sheets. The older of these sheets is commonly attributed to pre- to late Wisconsinan events, whereas the younger sheet is a product of the late Wisconsinan ice advance (Sirkin 1982). Two late Wisconsinan end-moraine lines cross Long Island (Schafer and Hartshorn 1965; Sirkin 1982; Stone and Borns 1986). The Ronkonkoma moraine, which marks the maximum extent of the late Wisconsinan glaciation, lies across central and southeastern Long Island, and extends eastward across the shelf in the direction of Block Island. To the north, a second moraine line (Harbor Hill-Roanoke Point-Charlestown) caps northern Long Island, Great Gull Island, and Fishers Island (Fig. 1), and extends eastward across southern Rhode Island. As the ice sheet retreated, meltwater was dammed behind the moraines, and pro-glacial lakes formed in the areas presently occupied by Block Island Sound (Bertoni et al. 1977) and Long Island Sound (Lewis and Stone 1991). During this time, coastal deltas prograded into the lakes, and thick deposits of fine-grained glaciolacustrine sediments accumulated on the lake bottoms (Lewis and DiGiacomo-Cohen 2000). The depression cut into the Harbor HillRoanoke Point-Charlestown moraine that forms the Race is inferred to be the spillway for glacial Lake Connecticut (Stone et al. 2005). Less prominent recessional moraines lie between the two major moraine belts on eastern Long Island and in southeastern Connecticut, and several of these have been mapped and described as double linear belts (Goldsmith 1982; Sirkin 1982; Stone et al. 2005). A consistent, late Wisconsinan-Holocene sequence of fluvial erosion (associated with the draining of the glacial lakes that occupied Long Island and Block Island sounds), followed by a marine transgression and a subsequent transition to present-day conditions, has been proposed for the marine areas surrounding the Race (Needell and Lewis 1984; Lewis and Stone 1991).

Circulation within Long Island Sound is tidally dominated. It is stronger in constricted areas such as the Race, where a large volume of water passes through a relatively narrow opening, and is weaker in broad, deeper basins (Signell et al. 2000). Scouring and redistribution of glacial and younger sediments by the strong tidal currents are common in eastern Long Island Sound and have also been observed in Block Island Sound (Needell and Lewis 1984). These currents have a 
significant influence on surficial sediment distributions in eastern Long Island Sound and western Block Island Sound (Poppe et al. 1998, 2000). Although wind-driven and wave-produced currents are relatively important in shallow nearshore areas, especially during aperiodic storms when strong winds blow the length of Long Island Sound, fresher water entering the western sound creates a longitudinal salinity gradient that imparts a weak gravitational circulation (Signell et al. 2000). This circulation combines with the tidal forcing at the Race to produce a complex residual circulation, whose dominant feature is a series of sound-wide counterclockwise gyres (Welsh 1993; Fig. 1). Together, these gyres carry offshore water from Block Island Sound westward through the Race along the north shore of Long Island Sound, and brackish water from the western sound eastward along the southern shoreline. Modeling suggests that this combination of tidal and estuarine circulation is an effective sediment transport mechanism (Signell et al. 2000).

\section{Materials and methods}

A 95-kHz Simrad EM1002 multibeam system mounted on the hull of NOAA Ship Thomas Jefferson was used to acquire over $560 \mathrm{~km}$ of survey lines from the deeper parts ( $>20 \mathrm{~m}$ water depth) of the study area during 2003. Two 29-foot launches with hull-mounted 455-kHz Reson 8125 and 240-kHz Reson 8101 systems acquired an additional $637 \mathrm{~km}$ of survey lines from shallower areas. The Simrad and Reson multibeam bathymetric datasets were combined to produce the continuous digital terrain model (DTM) shown in Fig. 2. Horizontal resolution of the data varies with water depth, but averages about $2 \mathrm{~m}$. Vertical resolution is about $0.5 \%$ of the water depth.

A dual-frequency Knudsen 320BR 2-7 kHz Chirp and 200-kHz echosounder system collected high-resolution seismic-reflection subbottom profile data. This system used hull-mounted transducers, and recorded in SEG-Y digital format. Boomer data from two previous State of Connecticut/USGS seismic cruises (Needell and Lewis 1984; Lewis and Needell 1987; Poppe et al. 2002) aided in the geologic interpretation of the multibeam data.

\section{Results}

The multibeam bathymetric data (Fig. 2) show distinctive patterns in the morphology of the seafloor which can be correlated with both underlying, seismically-detected geologic units, which appear to be partly or completely exposed in the study area, and with the effects of modern processes. These correlations have been used to construct the interpretive map presented in Figure 3. This map shows where exposed crystalline bedrock, coastal-plain, moraine, glaciolacustrine, and glaciodeltaic deposits are inferred to crop out or subcrop. The map also documents the effects of strong tidal currents, which include intense scour and coarse bedload transport, and the presence of gas-charged sediments. Isolated erosional remnants of younger deposits, lag deposits, and pockets of mobile sediment that are not of sufficient size to be distinguished are inferred to locally overlie and be interspersed with mapped units throughout the survey area.

\section{Discussion}

Ice-Sculpted Bedrock 
Avalonian bedrock is inferred to predominate in two fairly large areas in the northwestern part of the study area (Figs. 3, 4A, 5A). Characteristics that were used to delineate the bedrock include the presence of an irregular seismic reflection inferred to be acoustic basement, cropping out or subcropping so as to influence the morphology of the seafloor, a related pattern of "spiked" reflections indicative of boulders on the bottom, and an associated pattern of distinctive parallel ridges on the DTM.

The multibeam data reveal two sets of distinctive parallel ridges that are similar to terrestrial bedrock features of the adjacent Connecticut coast. One set trends northwest-southeast $\left(\sim \mathrm{N} 15^{\circ}\right.$ $\mathrm{W}$ ), similar to glacially-smoothed bedrock ridges that trend between $\mathrm{N} 15^{\circ}$ and $\mathrm{N} 20^{\circ} \mathrm{W}$ on land just west of the Thames River. These elongate ridges, which are similar in size, orientation, and morphology to their inferred offshore counterparts, parallel the interpreted direction of ice movement as shown by grooves and striations (Goldsmith, 1962).

The second set of ridges trends northeast-southwest $\left(\sim \mathrm{N} 60-70^{\circ} \mathrm{E}\right)$. These are similar to features on the east side of the Thames River, which trend between $\mathrm{N} 65^{\circ} \mathrm{E}$ and $\mathrm{N} 80^{\circ} \mathrm{E}$, and parallel the strike of foliation and the orientation of some jointing of the Avalonian anticlinorium. These ridges and their offshore counterparts were probably formed by glacial plucking and resemble strike ridges formed in dipping layered rock.

\section{Coastal-plain strata and older drift}

Coastal-plain strata of late Cretaceous age are reported to overlie the south-southeast dipping bedrock surface in the vicinity of Fishers Island (Fuller, 1905; Needell and Lewis, 1984). Although these unconsolidated to semi-consolidated gravels, sands, silts and clays are often difficult to distinguish from glacial drift in seismic reflection profiles, we used the multibeam data to differentiate coastal-plain strata from moraine on the basis of two criteria: the absence of surface boulders and the absence of minor ridges that parallel the overall trend of the mapped moraines (Fig. 3). On this basis, we mapped exposed or subcropping coastal-plain strata adjacent to and north of the Harbor Hill-Roanoke Point-Charlestown moraine (Fig. 6A).

A small, elongate ridge in the west-central portion of the survey area overlies bedrock, is more streamlined than the inferred coastal-plain outlier to the east, and is not bouldery (Fig. 3). The northwest-southeast orientation, lack of internal rhythmic layering, smoothness, and size of this feature suggest that it may be older glacial drift in the form of a drumlin.

\section{Moraines}

Three recessional end moraines are visible on the DTM (Figs. 2, 3). The largest, the Orient Point-Fishers Island segment of the Harbor Hill-Roanoke Point-Charlestown moraine, bisects the study area from southwest to northeast. Great Gull Island, Fishers Island, and the submerged ridge between them are formed by this moraine. Along the submerged ridge, the presence of surface boulders and small ridges parallel to the trend of the overall feature are inferred to indicate exposures of morainal deposits.

South of Fishers Island along the east side of the study area, a previously unrecognized, southwest-northeast trending morainal ridge has been exposed by erosion of the surrounding lake clay. This ridge exhibits smaller parallel ridges along its trend but appears to be more bouldery on its landward side than to the east. This phenomenon has been noticed farther to the west, in Long Island Sound, where lacustrine fans occur along former ice positions in glacial Lake Connecticut 
(Stone et al. 2005). Sirkin (1982) refers to a "recessional moraine envelope" that crosses Shelter Island and northern Gardiners Island. We infer that the newly recognized Block Island Sound ice position is a northeastward extension of this envelope.

The least prominent end moraine on the DTM, the Clumps moraine, is visible just west of Fishers Island (Fig. 4B). This moraine, which lies just north of and locally abuts the Harbor HillRoanoke Point-Charlestown moraine, trends to the northeast, where it controls much of the bathymetry in the central and southern parts of Fishers Island Sound (Lewis and Stone 1991; Poppe et al. 1998).

\section{Glaciolacustrine Sediments}

Erosional remnants of a seismic facies characterized by finely laminated, rhythmic, parallel internal reflectors that drape the underlying topography are exposed at three main locations (Figs. 2, 3, 5B). The largest exposure of this facies occurs along the northern wall of a depression southeast of Valiant Rock. There, angular slump blocks demonstrate the cohesive nature of these fine-grained sediments (Fig. 4D). There are other exposures along the western edge of the study area in Long Island Sound (Fig. 5D) and adjacent to the southern flank of the Fishers Island moraine segment in northwestern Block Island Sound. Numerous smaller exposures of this facies are also preserved within isolated bedrock lows in the northwestern part of the study area (Fig. 5A). Based on their seismic character and samples from coring studies (Bertoni et al. 1977; Poppe et al. 2002), we interpret these deposits to be varved, muddy, glaciolacustrine sediments that record deposition in Glacial Lake Connecticut northwest of the Race and in other pro-glacial lakes that were present in Block Island Sound.

\section{Glaciodeltaic Deposits}

A wedge of sediment laps over the northern flank of the Clumps moraine (Figs. 2, 3, 4B). This deposit has a distinctive seismic signature typified by seaward-dipping, oblique-tangential reflections in progradational clinoform configurations on seismic records that were run perpendicular to the Connecticut coast and by the presence of gas-charged sediment (Lewis and Needell 1987). We believe that these seismic reflections represent deltaic foreset and bottomset facies and that this deposit is a remnant of the Thames River glacial delta, an ice-marginal deltaic deposit that prograded into Glacial Lake Connecticut (Lewis and Stone 1991).

Kame and Esker

A sinuous, somewhat discontinuous ridge extends about $1.3 \mathrm{~km}$ southward from the Harbor HillRoanoak Point-Charlestown moraine just east of Great Gull Island (Fig. 4C). Near the moraine this ridge is about $60-\mathrm{m}$ wide, extends about $3 \mathrm{~m}$ above the surrounding seafloor, and has a hummocky crest. This ridge also progressively tapers, decreases in height, and smooths southward. We interpret this feature to be an esker and to represent glacio-fluvial deposition in contact with (i.e. beneath) stagnant ice (Banerjee and McDonald, 1975). A flattened broadening at its terminus may also represent an esker fan and its orientation suggests that the general drainage in this area during its formation was toward the south. This feature probably owes its preservation through the Holocene transgression and modern current regime to a coarse gravelly composition and(or) shelter provided by the east northeast-trending bathymetric high just to the south, which seismic profiles 
suggest may be composed of glacially-reworked glaciodeltaic or glaciolacustrine sediments. In any case, this interpretation suggests that stagnant ice remained, at least locally, behind this bathymetric high during formation of the Harbor Hill-Roanoak Point-Charlestown moraine.

An isolated conical bathymetric high is present about $0.7 \mathrm{~km}$ west of the ridge described above (Fig. 4C). We interpret this feature, which is approximately $70 \mathrm{~m}$ wide and $2.5 \mathrm{~m}$ high, to be the remnants of a kame. Kames are associated with eskers and are generally considered to be another stagnant ice-contact deposit that forms by the accumulation of glacio-fluvial debris in a fissure or hole in the ice (Garner, 1974). As the ice melts, the debris collapses to form these mound-like features.

\section{Scour}

Strong tidal currents have scoured and redistributed much of the glacial and younger sediment in easternmost Long Island Sound (Lewis and DiGiacomo-Cohen 2000). The intensity of this scour is evidenced by the large depressions adjacent to Valiant Rock, which in places now exceed $100 \mathrm{~m}$ in depth. The degradational processes associated with this scour include both erosion and mass-wasting, and the effects of both processes are visible in the multibeam data.

Erosional outliers appear as elongate wedge-shaped bathymetric highs with apexes that point upstream into the current and into constricted parts of the Race. Bottom samples and video from in and near the Race suggest that gravel armors much of the bottom (Poppe el al. 2000); however, gravel transported by currents may also be an abrading agent.

Examples of erosional outliers of exposed coastal-plain strata occur just west-southwest of Valiant rock (Fig. 6A).

Processes associated with mass-wasting are best exemplified by the conspicuous slump deposit located along the northern edge of the scour depression southeast of Valiant Rock (Fig. 4D). Seismic data show that the beds in this area are composed of glaciolacustrine sediments (Fig. 5B). Presumably, these layered strata contain alternating non-permeable cohesive and permeable non-cohesive beds that form weak planes allowing the sediments to break into blocks as they move downslope in the strong currents. The upper surfaces of the blocks are covered by asymmetrical sandwaves that suggest transport is toward the southeast and away from the Race. While a sharp erosional contact borders the northern edge of this feature, a 5-m high pile of excavated material is present on its eastern end. Elsewhere, tidal current-related scour is evidenced by the depressions around isolated boulders west of Great Gull Island and around the shipwreck located about $1.2 \mathrm{~km}$ east-southeast of Valiant Rock (Fig. 6E).

The strong oscillatory nature of the tidal currents is also illustrated by the three large circular scour depressions that flank Race Point (Fig. 6B). These rounded depressions range from $130-380 \mathrm{~m}$ wide and are $10-15 \mathrm{~m}$ deep. While tidal flow in the middle of the Race commonly exceeds $2 \mathrm{~m} / \mathrm{s}$, constriction of the gross tidal flow leads to increased current speeds off promontories, such as Race Point, and formation of characteristic eddy patterns of great competence (Pingree 1978; Poppe et al. 1999; Signell et al. 2000). As the swirling turbulent water in these fast eddies suspends and rolls gravelly sediment around in the depressions, impacts cause abrasion and the tearing of clasts from the walls and floor. In this manner continued erosion has created and enlarged these depressions. Similar features, albeit on a much smaller scale, are the cylindrical cavities or potholes found cut in stream beds. 


\section{Sand Waves}

At least 13 separate fields of large scale bedforms containing both giant sand waves and megaripples are present in the study area (Figs. 2,3). Nine fields were identified in western Block Island Sound, and four were found in easternmost Long Island Sound. These fields reflect the strength of the bottom currents and can be used to indicate directions of net sediment transport (Ludwick 1972). In general, most of the fields in the northern part of the study area exhibit sand wave asymmetry that indicates net transport is toward the west into Long Island Sound. Most of the fields in the southern part of the study areas exhibit sand wave asymmetry that indicates net transport is toward the east and out of the sound. Acoustic data collected along adjacent lines during opposite tides show that gross sandwave asymmetry does not change orientation with the tide. Whether this tidal independence of large bedform orientation is due to the spatial distribution of residual currents or to an asymmetry of current velocities is uncertain.

The most areally extensive sand wave field covers a well-defined, elongate roughly $4 \mathrm{~km}^{2}$ patch that extends from near Valiant Rock, the isolated bathymetric high in the middle of the Race, to the southeastern corner of the study area in western Block Island Sound where the field widens significantly (Figs. 2,3 ). The modern surficial sand sheet that comprises the field is relatively thin (1-5 $\mathrm{m}$ in the troughs between the sand waves) and overlies an irregular wave-cut surface on post-glacial fluvial and estuarine sediments (Needle and Lewis 1984; Fig. 5C)

The sand waves in this field can be divided into two distinct areas based on morphology, and crests of the sand waves bifurcate at the contact between these areas. The sand waves along the southern edge and throughout most of the southern part of the field are formed in gravelly sand (Poppe et al. 2000) and generally increase in both height and wavelength toward the southeast. Crest-to-trough heights there reach $7.85 \mathrm{~m}$ and wavelengths, although irregular, average more than $150 \mathrm{~m}$ and can exceed $180 \mathrm{~m}$ (Figs. 5C, $6 \mathrm{C}$ ). The sand waves in this part of the field are asymmetrical with slip faces that are oriented toward the southeast and have relatively straight to smoothly sinuous crests. Stoss slopes of the sand waves in this part of the field range from $13-15^{\circ}$. Slip faces are steeper, averaging $19-23^{\circ}$. This asymmetry suggests a flow-transverse crest orientation and net sediment transport toward the southeast. Megaripples, which mimic the asymmetry of the sand waves, are ubiquitously present in the stoss slopes and between the sand waves. The presence of these megaripples on the sand waves suggests that transport is active and that the sand waves are propagating under the present hydraulic regime (Dalrymple et al. 1978; Reineck and Singh 1980).

Conversely, sand waves in the northwestern part of this field are more regularly spaced, but have average heights of less than $2 \mathrm{~m}$ and periods of less than $24 \mathrm{~m}$. Although some of the sand waves in the northwestern part of the field are symmetrical, most are asymmetrical with slip faces oriented toward the northwest. Sand wave asymmetry indicates that transport here is toward the northwest and into Long Island Sound.

Three large barchanoid sand waves occur northwest of Great Gull Island (Figs. 2, 3, 5D, 6D). These waves, which typically form in currents that are unidirectional, appear as crescent-shaped features in planar view, are convex westward, and partially overlap. This overlap appears to have caused asymmetry that results in features with extremities (horns) 
of different length. Crescent width measured from the tip of the shortest extremity to the tip of its opposing side on the middle of the barchanoid sand wave approaches $970 \mathrm{~m}$.

Inasmuch as the horns of barchanoid dunes extend down current because they migrate faster than the main body (McKee 1966), the morphology of these waves indicates a net eastward transport of sediment into the Race. Asymmetry of straight-crested sand waves, which are present south of the middle barchanoid sand wave and on the southern flank of the southern barchanoid sand wave, and of scour marks around nearby boulders also indicates net eastward transport. Highresolution seismic-reflection data show that the barchanoid waves reach heights of $7 \mathrm{~m}$ over the seafloor on their up-current (western) sides (Fig. 5D). The seismic data also indicate that the stoss and slip faces have similar slopes and that these features, if mobile, are prograding over exposed glaciolacustrine sediment.

\section{Pock Marks}

Numerous circular to oblate depressions are concentrated in a roughly $8.6 \mathrm{~km}^{2}$ area north of the Clumps moraine off the western tip of Fishers Island (Figs. 2, 3, 4B). The depressions are typically between $5-6 \mathrm{~m}$ in diameter and extend about $0.2-0.3 \mathrm{~m}$ below the surrounding seafloor, but individual depressions range up to $24 \mathrm{~m}$ in diameter and $1.1 \mathrm{~m}$ in depth. At several places the depressions overlap, forming larger depressions that exceed $50 \mathrm{~m}$ across.

We interpret these features to be pockmarks that formed during the escape of biogenic methane from underlying sediments of the Thames River glacial delta (Lewis and DiGiacomoCohen 2000). Gas-charged sediments have been previously reported in this delta (Lewis and Needell 1987) and pockmarks and gas-charged sediments have been reported nearby in Fishers Island Sound (Poppe et al. 1998). The source of the methane in these sediments is uncertain, but it probably originates from organic matter trapped in the rapidly deposited sediments of the delta. In any case, the asymmetry of many of the depressions is evidence that modern currents are at least partly responsible for the character and maintenance of these features.

\section{Anthropogenic Artifacts}

Anthropogenic influences on the bathymetry can be seen in several places in the study area. Of interest to historians and the diving community is the previously uncharted wreck of the VOLUND, which lies southeast of Valiant Rock in approximately $30 \mathrm{~m}$ of water (Kimball 2003; Fig. 6E). This 239-foot Norwegian tramp steamer sank on September 26, 1908 after a collision with the passenger vessel COMMONWEALTH. An asymmetrical scour depression around the shipwreck is evidence for net transport to the west-northwest in this part of the Race.

Part of the New London dump site is visible in the north-central portion of the study area, most obviously in the vicinity of the narrow swath of data that extends northward from the bulk of the multibeam DTM toward the mouth of the Thames River (National Ocean Service 1994; Fig. $6 \mathrm{~F}$ ). Here the "orange peel" appearance of the bathymetry is caused by multiple mounds of dumped dredge spoils ranging in size from approximately 10 to $30 \mathrm{~m}$ across and having vertical relief of 0.3 to 1.5 meters.

\section{Conclusions}


The detailed multibeam bathymetry and subbottom seismic-reflection data presented here yield a new geologic perspective and reveal previously unknown details of a dynamic seafloor surface. Extensive tidal action over the past 15,000 years has removed much of the glacial and younger sediment that once filled eastern Long Island and northwestern Block Island sounds (Lewis and Stone 1991). Based on geomorphological and acoustic characteristics of the complex topography resulting from this erosion, we have been able to interpret the exhumed glacial features and delineate the ongoing sedimentary processes.

The dominant glacial features in the study area are the northeast-trending Harbor HillOrient Point-Charlestown moraine, the Clumps moraine, and another smaller, previously unknown, recessional moraine. Exposed remnants of fine-grained glaciolacustrine sediments are scattered around the study area, and part of the Thames River glacial delta is visible along its northern edge. A streamlined sediment ridge overlying bedrock is interpreted to be a drumlin, and a south-trending sinuous ridge and an isolated bathymetric high associated with the largest moraine are interpreted to be an esker and kame, respectively. Southeastward-trending elevated lineations observed on the exposed bedrock in the northwestern part of the study area parallel the striations and streamlined hills of onshore formations. Also, several irregular elevated lineations on the bedrock surface trend southwestward and parallel structural trends in the onshore Avalonian terrane and, therefore, probably represent ice-plucked strike ridges. Together, these lineations show that the effects of glaciation on the bedrock continue offshore under Long Island Sound.

The strong tidal currents have produced large bathymetric depressions adjacent to the Race that exceed $100 \mathrm{~m}$ in depth. Degradational processes that caused these scour depressions include seabed erosion and mass-wasting, and effects of both processes are visible on the DTM as erosional outliers and slump blocks.

Asymmetry of transverse sand waves, barchanoid dune orientation, and scour around isolated boulders and a shipwreck indicate that net transport is primarily toward the west and into Long Island Sound across the northern part of the study area, but primarily toward the east and out of the Sound across the southern part. This pattern of sediment movement supports previously untested bottom circulation and transport models produced for eastern Long Island Sound (Welsh 1993; Signell et al. 2000).

\section{Acknowledgements}

We would like to thank the officers and crew of NOAA Ship Thomas Jefferson, without whose concentrated team effort creation of this DTM would not have been possible. This work was supported by the Coastal and Marine Geology Program of the U.S. Geological Survey, the Connecticut Department of Environmental Protection, and the Atlantic Hydrographic Branch of the National Oceanic and Atmospheric Administration. This manuscript has benefited from critical reviews by Kathy Scanlon, Rob Thieler, and Jim Robb (all USGS).

\section{References}

Banerjee I, McDonald BC (1975) Nature of esker sedimentation In: Jopling AC, McDonald BC (eds.), Glaciofluvial and glaciolacustrine sedimentation. Soc Econ Paleontol Mineral Spec Publ 23: 132-154 
Bertoni R, Dowling JJ, Frankel L (1977) Fresh-water lake sediments beneath Block Island Sound. Geology 5: 631-635

Dalrymple RW, Knight RJ, Lambiase JJ (1978) Bedforms and their hydraulic stability relationships in a tidal environment, Bay of Fundy, Canada. Nature 275: 100-104

Fuller ML (1905) Geology of Fishers Island, New York. Geol Soc Am Bull 16: 367-390

Fuller ML (1914) The geology of Long Island, New York. US Geological Survey Prof Pap 82

Garner HF (1974) The origin of landscapes - a synthesis of geomorphology. Oxford University Press, New York

Goldsmith R (1962) Surficial geology of the New London quadrangle, Connecticut - New York. US Geological Survey Map GQ-176

Goldsmith R (1982) Recessional moraines and ice retreat in southeastern Connecticut. In: Larson GJ, Stone BD (eds.), Late Wisconsinan glaciation of New England. Kendall/Hunt, Dubuque, Iowa, IA, pp 61-76

Grim MS, Drake CL, Hertzler JR (1970) Sub-bottom study of Long Island Sound. Geol Soc Am Bull 81: 649-666

Hermes OD, Gromet LP, Murray DP (1994) Bedrock geologic map of Rhode Island. Office of the Rhode Island State Geologist, Rhode Island Map Series no. 1, scale 1:100,000

Kimball CW (2003) Fateful steamer collision could answer question of mystery ship in the Race. The Day, New London, CT, Tuesday November 17 edition, pp 1

Lewis RS, Needell SW (1987) Maps showing stratigraphic framework and Quaternary geologic history of eastern Long Island Sound. US Geological Survey Miscellaneous Field Studies Map MF1939-A, scale 1:125,000

Lewis RS, Stone JR (1991) Late Quaternary stratigraphy and depositional history of the Long Island Sound Basin: Connecticut and New York. J Coastal Res Spec Issue 11: 1-23

Lewis RS, DiGiacomo-Cohen ML (2000) A review of the geologic framework of the Long Island Sound basin with some observations relating to postglacial sedimentation. J Coastal Res 16: 522532

Ludwick JC (1972) Migration of tidal sand waves in Chesapeake Bay entrance. In: Swift DJP, Duane DB, Pilkey OH (eds) Shelf sediment transport: process and pattern. Dowden, Hutchinson, and Ross, Stroudsburg, PA, pp 377-410 
McKee ED (1966) Structures of dunes at White Sands National Monument, New Mexico (and a comparison with structures of dunes from other selected areas). Sedimentology 7: 1-69

McMaster RL, La Chance TP, Garrison LE (1968) Seismic-reflection studies in Block Island and Rhode Island Sounds. Am Assoc Petrol Geol Bull 52: 465-474

McMaster RL, Ashraf A (1973) Subbottom basement drainage system of inner continental shelf off southern New England. Geol Soc Am Bull 84: 187-190

Mosher DC, Thomson RE (2002) The Foreslope Hills: large-scale, fine-grained sediment waves in the Strait of Georgia, British Columbia. Mar Geol 192: 275-295

Needell SW, Lewis RS (1984) Geology of Block Island Sound, Rhode Island and New York. US Geological Survey Miscellaneous Field Studies Map MF-1621, scale 1:125,000

National Ocean Service (1994) Long Island Sound - eastern part. National Oceanic and Atmospheric Administration, Washington, D.C., Chart 12354, 33rd edition, scale 1:80,000

Pingree RD (1978) The formation of the Shambles and other banks by stirring of the seas. J Mar Biol Assoc UK 58: 211-226

Poppe LJ, Lewis R, Denny JF, Parolski KF, DiGiacomo-Cohen ML (1998) Sidescan sonar image, surficial geologic interpretation, and bathymetry of Fishers Island Sound, Connecticut, New York, and Rhode Island. US Geological Survey Investigations Map I-2640, 2 sheets, scale 1:12,500 and $1: 15,000$

Poppe LJ, Lewis RS, Signell RP, Knebel HJ, Persaud M, Denny JF, Parolski KF, DiGiacomoCohen ML (1999) Sidescan sonar image, surficial geologic interpretation, and bathymetry of the Long Island Sound sea floor off Roanoke Point, New York. US Geological Survey Geologic Investigations Map I-2692, 2 sheets, scale 1:15,000 and 1:20,000

Poppe LJ, Knebel HJ, Mlodzinska ZJ, Hastings ME, Seekins BA (2000) The distribution of surficial sediments in Long Island Sound and adjacent waters: texture and total organic carbon. J Coastal Res 16: 567-574

Poppe LJ, Paskevich VF, Lewis RS, DiGiacomo-Cohen ML (2002) Geologic framework data from Long Island Sound, 1981-1990: a digital data release. US Geological Survey Open-File Rep 02002, DVD-ROM

Poppe LJ, Foster DS, Danforth WW, (2006) Character and distribution of exposed glaciodeltaic deposits off outer Cape Cod, Massachusetts, and their effects on hydrogeology and benthic habitats. Geo-Mar Lett xx: in press

Reineck HE, Singh IB (1980) Depositional sedimentary environments. Springer, Berlin Heidelberg New York 
Rodgers J (compiler) (1985) Bedrock geological map of Connecticut. Connecticut Natural Resources Atlas Series, Connecticut Geological and Natural History Survey, Hartford, CT, scale $1: 125,000$

Schafer JP, Hartshorn JH (1965) The Quaternary of New England. In: Wright HE, Frey DG, (eds), The Quaternary of the United States. Princeton University Press, Princeton, NJ, pp 113-128

Signell RP, List JH, Farris AS (2000) Bottom currents and sediment transport in Long Island Sound: a modeling study. J Coastal Res 16: 551-566

Sirkin LA (1976) Block Island, Rhode Island - evidence of fluctuation of the late Pleistocene ice margin. Geol Soc Am Bull 87: 574-580

Sirkin LA (1982) Wisconsinan glaciation of Long Island, New York to Block Island, Rhode Island. In: Larson GJ, Stone BD (eds) Late Wisconsinan glaciation of New England. Dubuque, IA, Kendall/Hunt, pp 35-60

Stone BD, Borns HW (1986) Pleistocene glacial and interglacial stratigraphy of New England, Long Island and adjacent Georges Bank and Gulf of Maine. In: Sibrava V, Bowen DQ, Richmond GM (eds), Quaternary glaciations in the northern hemisphere. Pergamon Press, Oxford, pp 39-52

Stone JR, Schafer JP, London EH, DiGiacomo-Cohen M, Lewis RS, Thompson WB (2005) Quaternary geologic map of Connecticut and Long Island Sound basin. US Geological Survey, Scientific Investigations Map 2784, 2 sheets, scale 1:125,000

Suter R, de Laguna W, Perlmutter NM, Brashears ML (1949) Mapping of geologic formations and aquifers of Long Island, New York. New York Water Power and Control Commission Bull GW-18

ten Brink, US, Danforth, WW, Polloni, CF, Andrews, B, Llanes Estrada P, Smith S, Parker E, Uozumi T (2004) New seafloor map of the Puerto Rico Trench helps assess earthquake and tsunami hazards in the northeast Caribbean. Eos, Trans Am Geophys U, 85: 349

Todd BJ, Fader GB, Courtney RC, Pickrill RA (1999) Quaternary geology and surficial sediment processes, Browns Bank, Scotian Shelf, based on multibeam bathymetry. Mar Geol 162: 165-214

Welsh BL (1993) Physical oceanography of Long Island Sound: an ecological perspective. In: Van Patten MS (ed) 1992 Long Island Sound Research Conf Proc, CT-SG-93-03, pp 23-33

Fig. 1 Map showing location of the study area (hatched polygon). Also shown are major onshore moraines, the sites of other interpreted multibeam and sidescan sonar surveys (USGS: shaded polygons; NOAA: open polygons), and a generalized circulation model (shaded arrows; Welsh 1993) 
Fig. 2 Digital terrain model (DTM) of the seafloor in eastern Long Island and western Block Island sounds produced from multibeam bathymetry data. Image is sun-illuminated from the north, and vertically exaggerated $8 \mathrm{X}$. Colors trending toward red are shallower areas, and those trending toward blue are deeper areas. See key for depth ranges

Fig. 3 Geological interpretation of the DTM. Arrows show directions of net sediment transport, based on sand wave asymmetry. Also shown are the locations of the seismic profiles in Fig. 5, and the detailed multibeam views of the seafloor in Figs. 4 and 6. Blank areas are largely coarse Holocene sediments reworked from the underlying glacial units (Needell and Lewis 1984; Lewis and Needell 1987)

Fig. 4a-d Detailed views of the multibeam DTM showing exposed glacial features. a Bedrock surface in the northwestern part of the study area. Glacially-smoothed bedrock ridges parallel similar features and glacial striations onshore; strike ridges parallel those of the onshore Avalon Terrane. b Bouldery surface of the Clumps Moraine. Circular to oblate depressions to the north are interpreted to be pockmarks that formed during the escape of biogenic methane. $\mathbf{c}$ Sinuous hummocky ridge interpreted to be an esker and conical mound interpreted to be a kame. d Mass wasting of glaciolacustrine sediments southeast of Valiant Rock. Locations of these views are shown in Fig. 3

Fig. 5a-d Chirp high-resolution seismic-reflection profiles. a Bedrock surface in the northwestern part of the study area. Note the glaciolacustrine sediments preserved in isolated lows. b Layered appearance of fine-grained glaciolacustrine sediments. $\mathbf{c}$ Large transverse sand waves southeast of Valiant Rock. Asymmetry shows net sediment transport is toward the east; megaripples on sand waves suggest that transport is active. d Transect through a barchanoid sand wave northwest of Valiant Rock that is prograding over glaciolacustrine sediments. Interpretations are partly based on planar morphologies in the DTM. Locations of seismic profiles are shown in Fig. 3

Fig. 6a-f Detailed views of the multibeam DTM showing sedimentary processes and anthropogenic artifacts. a Wedge-shaped erosional outliers of coastal-plain strata present west-southwest of Valiant rock. b Circular point-associated scour depressions, presumably formed by strong eddies off Race Point. c Transverse sand waves east-southeast of Valiant Rock. Asymmetry suggests westerly net transport dominates north of the crest bifurcation, and easterly net transport dominates on the south side. Megaripples on sand waves suggest that transport is active. $\mathbf{d}$ Barchanoid sand wave northwest of Great Gull Island showing net transport there is to the east. e Wreck of the Volund, a steamer that sank in 1908 (Kimball 2003), located immediately southeast of Valiant Rock. Note intense scour, suggesting net sediment transport to the west. f New London dump site with mounded dredge spoils. Locations of detailed views are shown in Fig. 3 


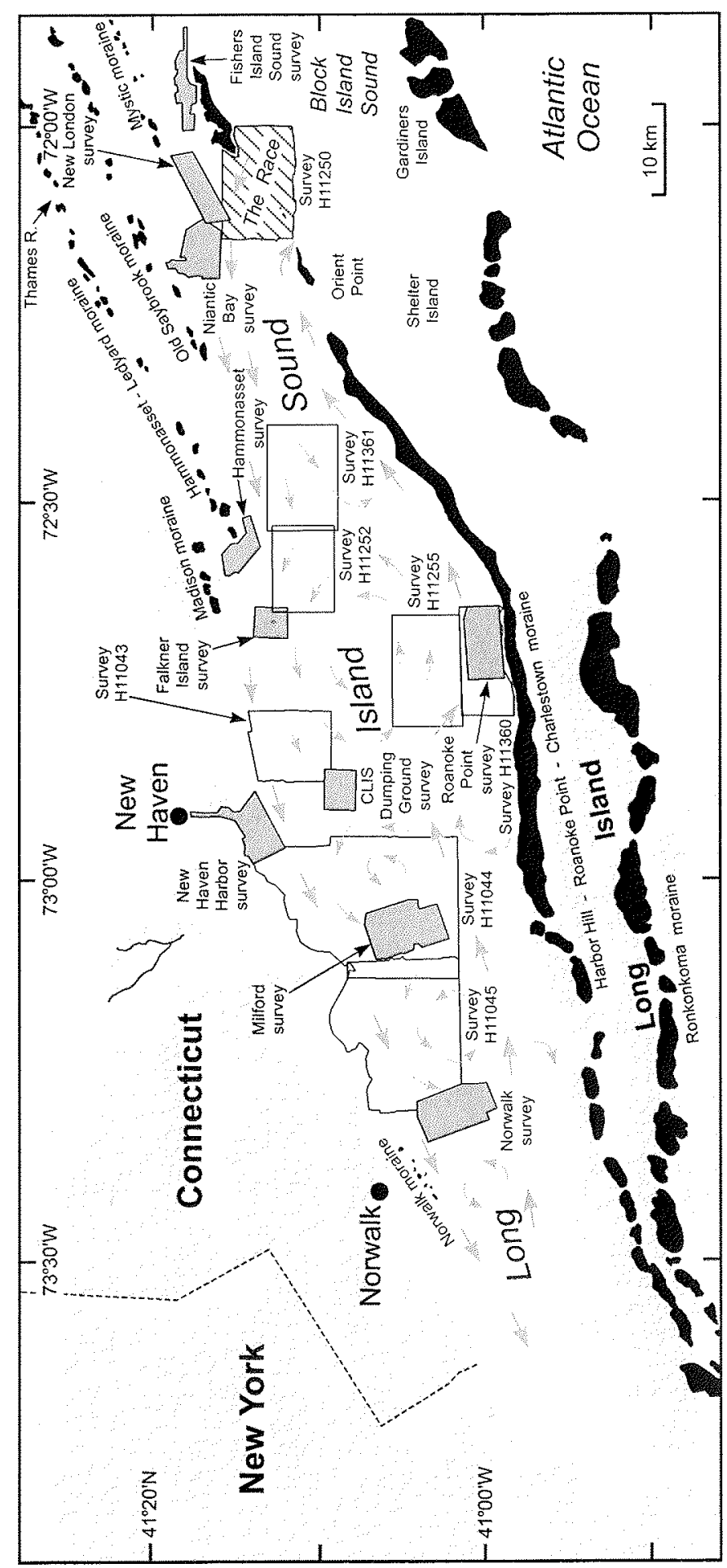




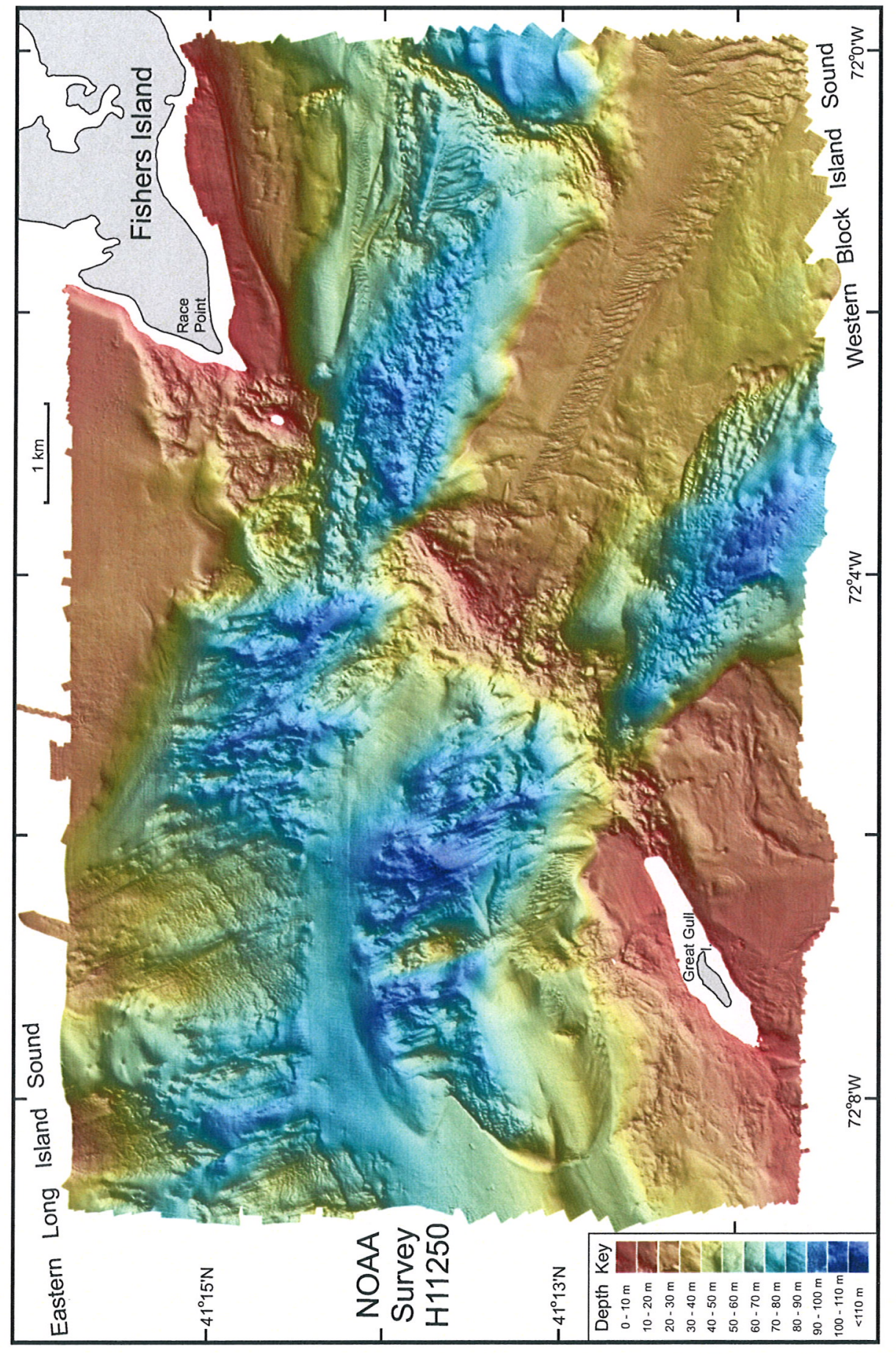




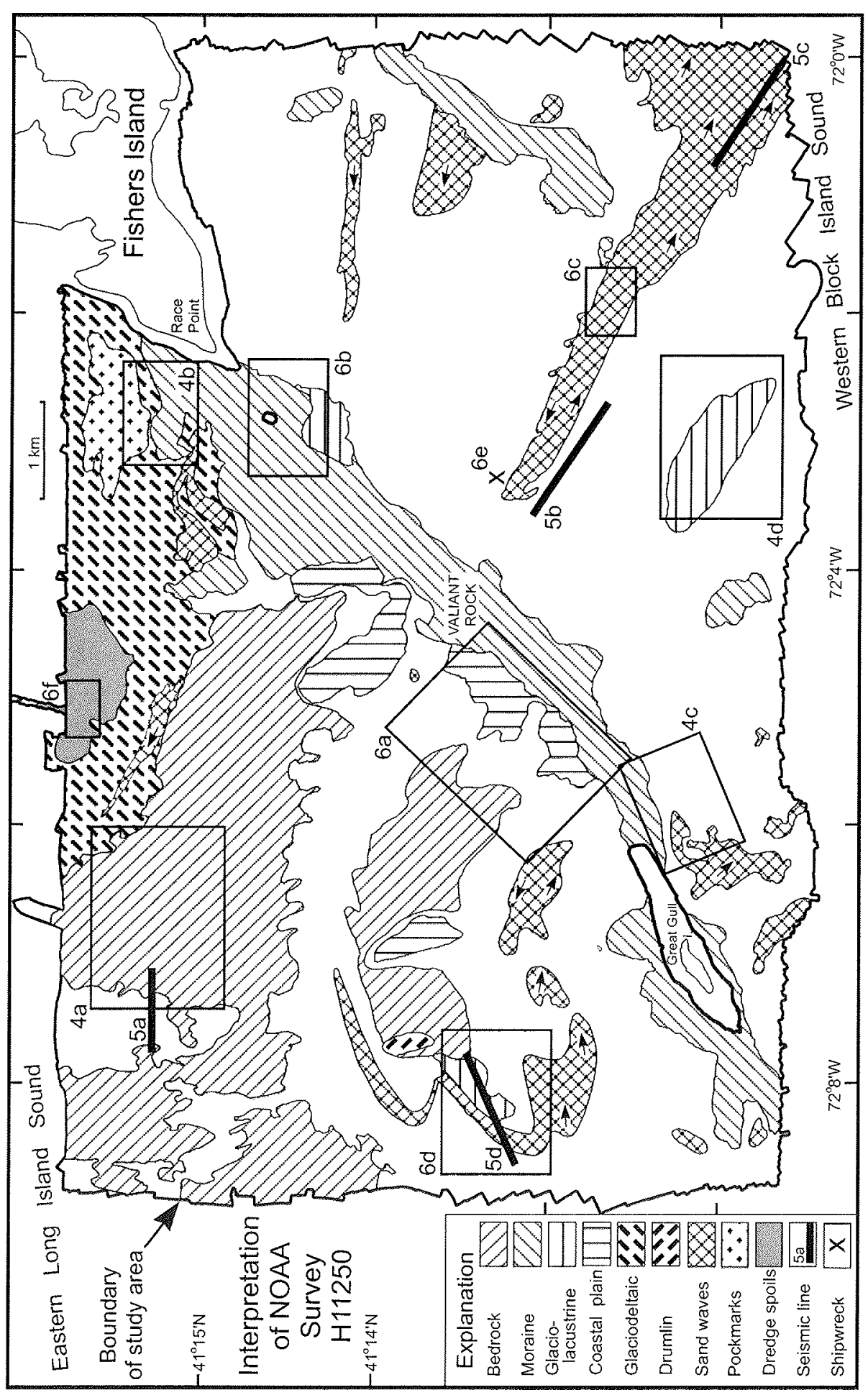



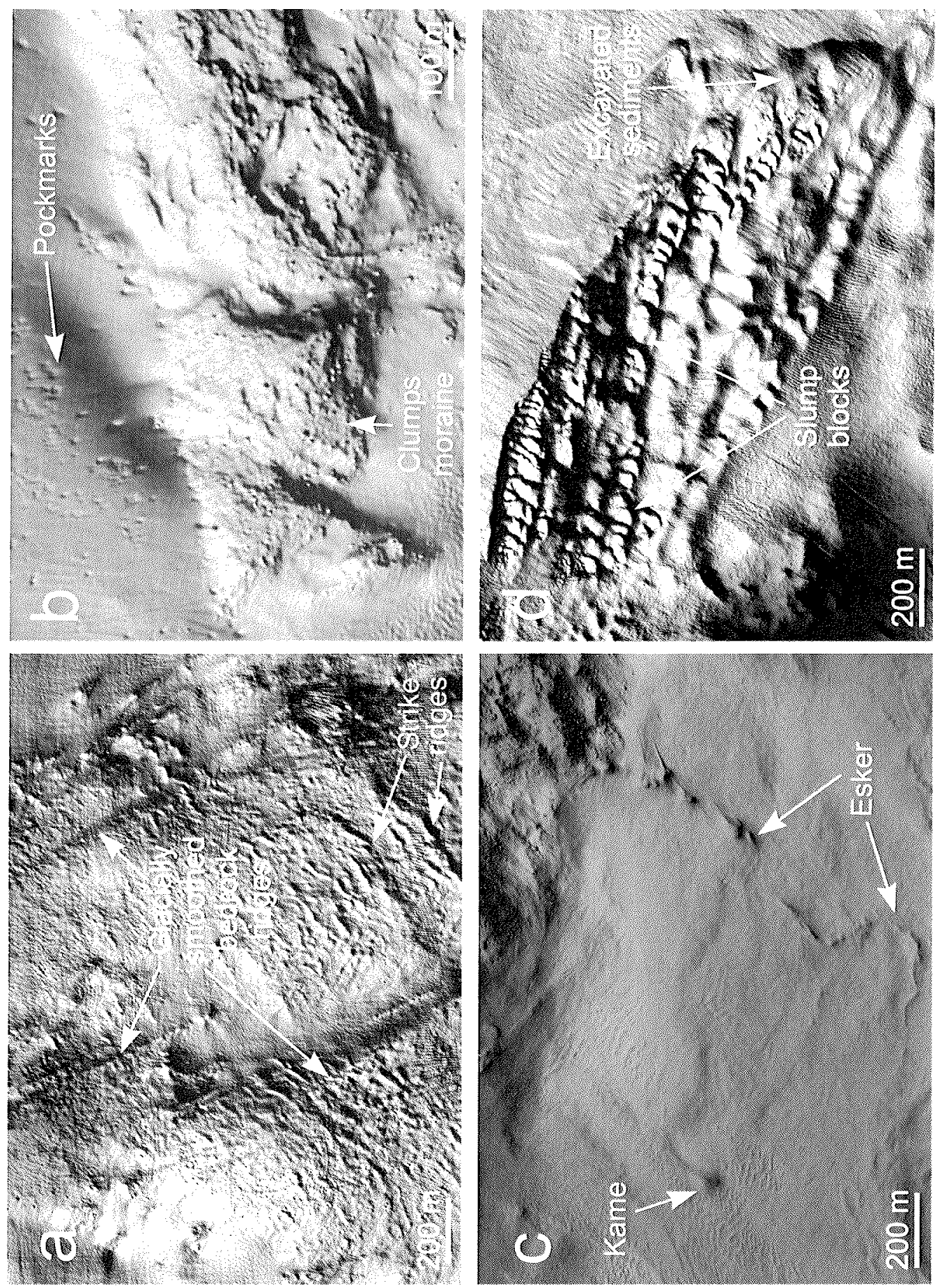

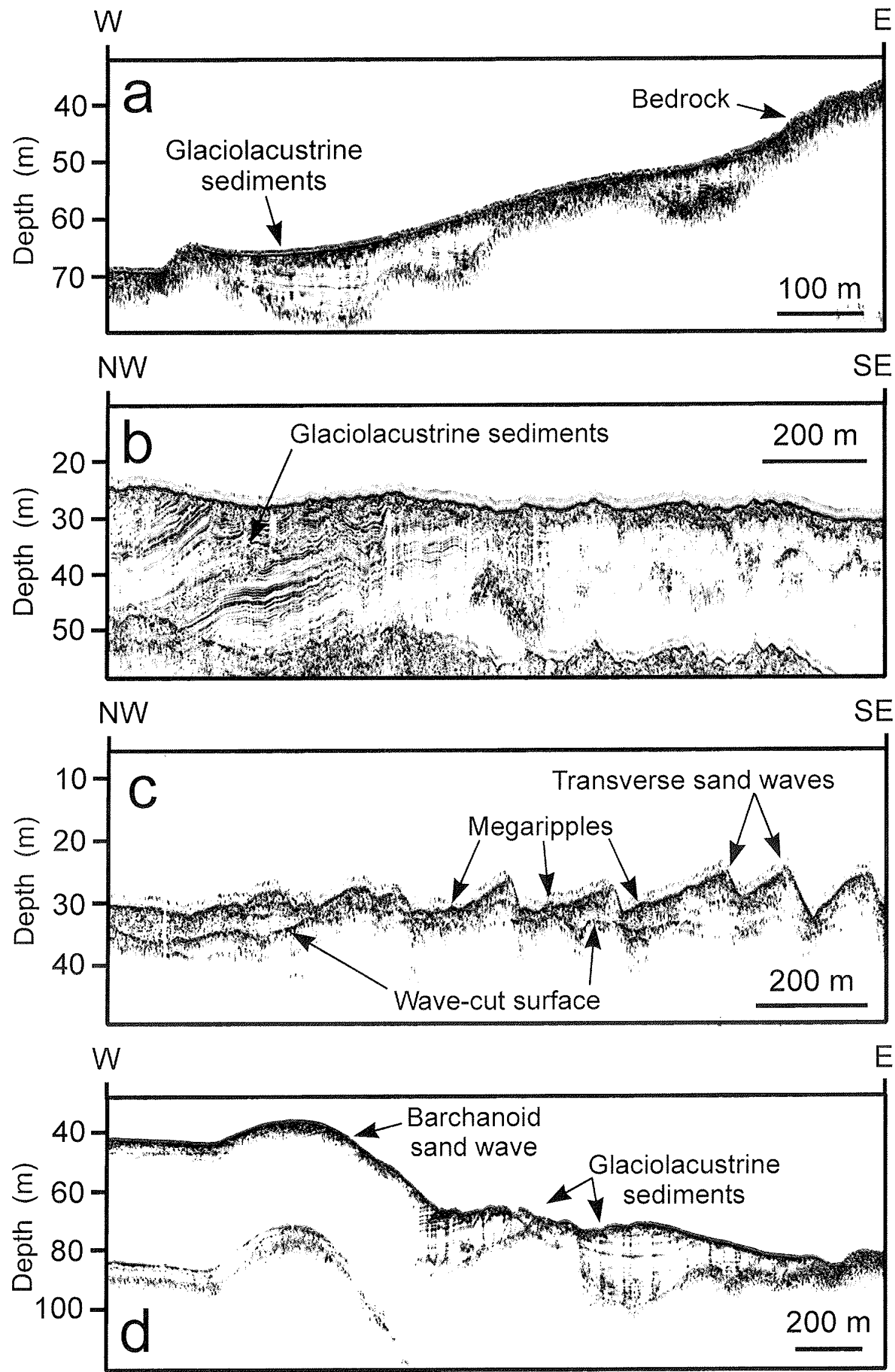

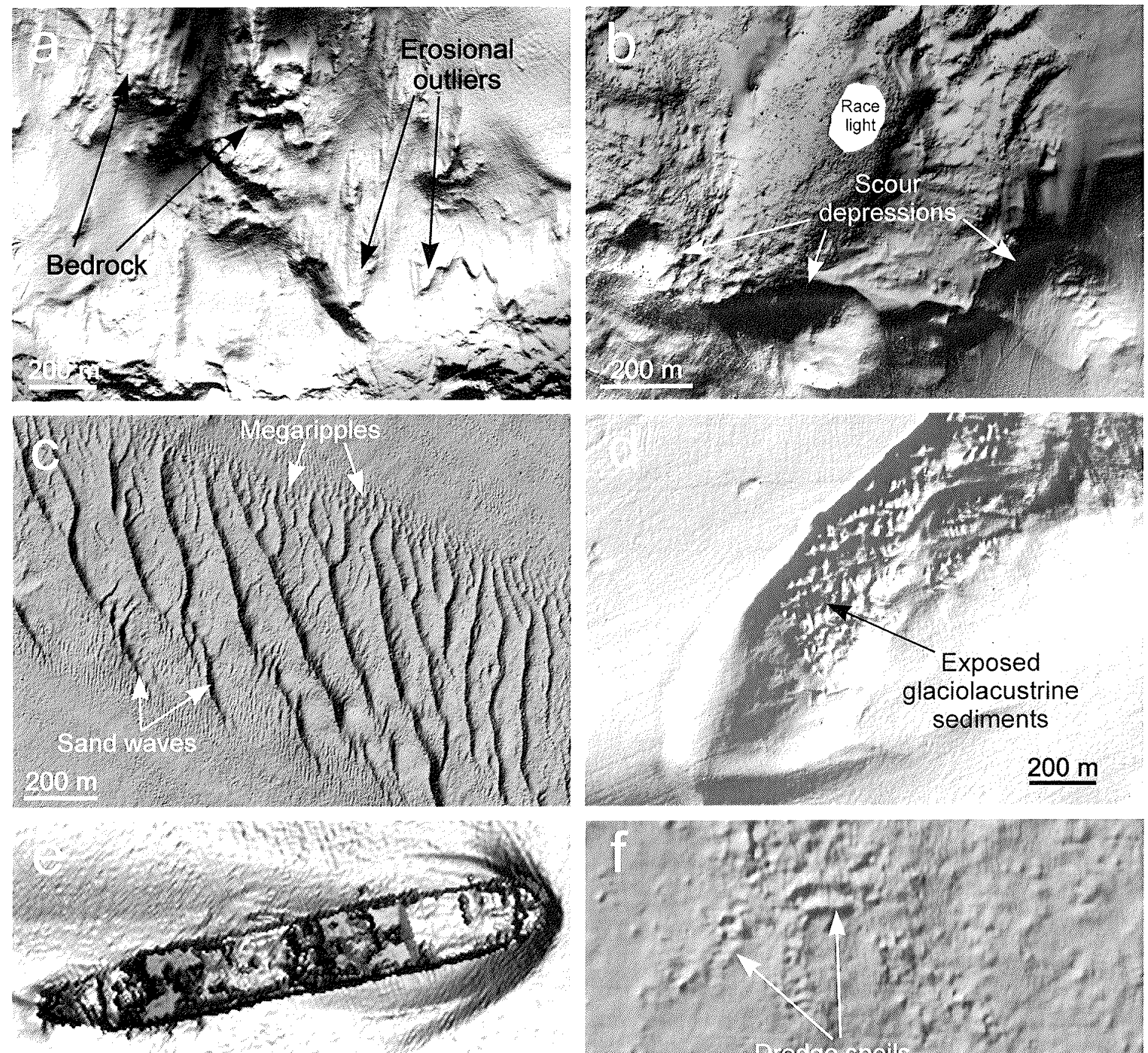

$10 \mathrm{~m}$

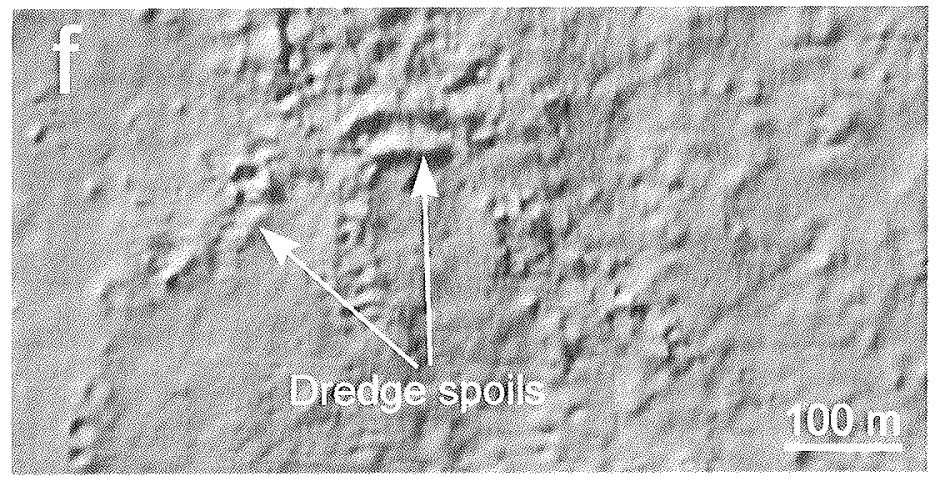

